\title{
Austrian and Post-Marshallian Economics The Bridging Work of George Richardson
}

\author{
Foss, Nicolai J.
}

Document Version

Final published version

Publication date:

1996

\section{License \\ CC BY-NC-ND}

Citation for published version (APA):

Foss, N. J. (1996). Austrian and Post-Marshallian Economics: The Bridging Work of George Richardson. DRUID - Danish Research Unit for Industrial Dynamics. DRUID Working Paper No. 96-04

Link to publication in CBS Research Portal

\section{General rights}

Copyright and moral rights for the publications made accessible in the public portal are retained by the authors and/or other copyright owners and it is a condition of accessing publications that users recognise and abide by the legal requirements associated with these rights.

Take down policy

If you believe that this document breaches copyright please contact us (research.lib@cbs.dk) providing details, and we will remove access to the work immediately and investigate your claim. 


\title{
$\mathbf{D}_{\text {ANSH }} \mathbf{R}_{\text {ESEARCH }} \mathbf{U}_{\text {NIT FoR }} \mathbf{I}_{\text {NDUSTRIAL }} \mathbf{D}_{\text {YNAMICS }}$
}

\author{
DRUID WORKING PAPER NO. 96-4
}

Austrian and Post-Marshallian Economics:

The Bridging Work of George Richardson

by

Nicolai J. Foss

April 1996

ISSN 1396-2035 


\title{
Austrian and Post-Marshallian Economics: The Bridging Work of George Richardson
}

\author{
by \\ Nicolai J. Foss \\ Institute of Industrial Economics and Strategy \\ Copenhagen Business School \\ Nansensgade 19,6 \\ 1366 Copenhagen $\mathrm{K}$ \\ Denmark \\ Phone +45 38152547 \\ Fax +45 38152540 \\ E-Mail ESNJF@cbs.dk \\ Forthcoming in \\ Nicolai J. Foss \& Brian J. Loasby, eds.: \\ Capabilities and Coordination: \\ Essays in Honour of G.B. Richardson.
}

\begin{abstract}
Austrian and post-Marshallian economics share a number of concerns, such as a basic subjecticist stance and an emphasis on the importance of inquiry into the disequilibrium market process. This paper details similarities and differences between these two bodies of thought, and argue that a closer liaison is possible. George Richardson's work is presented as a possible bridge, since his work incorporates both Austrian and post-Marshallian elements. The paper ends by sketching a combined Austrian and post-Marshallian approach to the firm.
\end{abstract}

\section{Keywords}

Austrian economics, post-Marshallian economics, George Richardson, the theory of the firm.

\section{JEL Classification}

$B 13, B 25, D 20$

ISBN 87-7873-003-1 


\section{Introduction $^{1}$}

At first glance, there seems to be little similarity between Austrian and post-Marshallian economics. On the one side we have one of the three distinct marginalist traditions, originating in Austria in 1871, and recently flourishing in the United States (Vaughn 1994). In its modern incarnation, the Austrian school has laid particular emphasis on economic methodology and research into the entrepreneurial role in the market process. On the other side, we confront representatives of the genuine Marshallian tradition, who have mainly written on industrial organization and firm behavior.

In contrast, Austrians have written relatively little on these subjects, and do not seem to have been particularly comfortable with Marshallian doctrines. For example, to Austrians Marshall's half-way house between Ricardian cost theory and subjective value theory is a hopeless muddle that neglects the utility dimension of costs; his understanding of economics as being occupied with material well-being smack of an objectivism that is foreign to Austrian subjectivism; and Marshall's claim that "Economics contains no long chains of deductive reasoning" (1925: 781) will certainly not appeal to Austrians brought up on von Mises' apriorist methodology. On the whole, there seems to be numerous and deep differences between the Marshallian and the Austrian traditions.

However, in a broader perspective, the differences between Marshall and at least some of the Austrians, particularly Carl Menger, may be smaller than their differences from the kind of neoclassical economics that became dominating during the 1930s. In fact, as Brian Loasby (1993b) tells his "counter-factual history of twentieth century economics", the leaders of the anti-Walrasian opposition were Menger and Marshall, who shared the central concern of (some of) the classical economists: the growth and organization of productive knowledge. Per implication, Mengerians and Marshallians may share similar concerns.

In this paper I relate to this more conciliatory reading of the Marshallian/Austrian relation. I begin by providing a brief and admittedly somewhat superficial tour d'horizon, and argue that the ideas of Marshall's true heirs - from D.H. MacGregor over Philip Andrews, Edith Penrose, Jack Downie, and George Richardson to Brian Loasby - in a number of dimensions are closely related to Austrian doctrines ("Marshall, the PostMarshallians, and Austrian Economics"). Both traditions are ultimately deeply concerned with change, including unanticipated change, and how to effectively adapt to such change.

In particular, this emphasis on change is accompanied by an understanding of

\footnotetext{
${ }^{1}$ Excellent comments from Richard Arena, Peter Earl, Brian Loasby, Jaques Ravix, and George Richardson on earlier versions of this paper are gratefully acknowledged. Some of the sections in this paper draw on my earlier work on Richardson (Foss 1994c,1995).
} 
institutions and organizations as means to adapt to change. For example, the Austrians had at least since the socialist calculation debate of the 1930s a clear grasp of the incentive properties of alternative institutions, but their later emphasis on the growth and coordination of knowledge does not in all dimensions reduce to static incentive considerations.

Relatedly, the post-Marshallian understanding of the firm as a repository of productive knowledge is quite different from the modern contractual view of firms as incentive systems (Holmstrom \& Milgrom 1994). Both the Austrian and the postMarshallian perspectives on economic organization are therefore distinct from the contemporary Coasian strand of organizational economics.

More focus on the Austrian/post-Marshallian connection is provided by an attempt to uncover those themes that are particularly germane to Austrian economics in the work of George Richardson ("George Richardson: Austrian Problems and Marshallian Answers"). While Richardson's contributions have not been completely unnoticed among Austrian economists ${ }^{2}$, I am not aware of any comprehensive analysis of the similarities. But they are there; and the more obvious similarities have to do with Richardson's concern with the coordination problem, his welfare economics, his process view of the market, his subjectivism, and his Marshallian view of markets and their various "imperfections" as information structures. Because of this, Richardson's work is particularly likely to serve as a bridge for a future dialogue between Austrians and post-Marshallians. Specifically, I argue that points of contact may well lie in the emerging "capabilities perspective" on the firm that in many respects reflect the issues that have traditionally been central to Austrians and postMarshallians ("Austrian and Post-Marshallian Economics: The Theory of the Firm").

\section{Marshall, the Post-Marshallians, and Austrian Economics}

That it may be worthwhile to examine the Austrian/post-Marshallian connection is indicated by, for example, Earl's (1983: 91) reference to a group of "...English economists who have been concerned...with the theory of the firm in its market context...[and] share a...subjectivists, disequilibrium view". Now, Austrians traditionally have not been much concerned with "the theory of the firm in its market context", but they too share "a subjectivist, disequilibrium view", that goes back - in its essentials - to Menger (Streissler

\footnotetext{
${ }^{2}$ See Kirzner (1962: 380n, 1973: 93n), O'Driscoll \& Rizzo (1985: 90,223), and Lachmann (1986: 8,11,57n). Littlechild (1976: 16) mentions Richardson along with Loasby and Shackle, and observes that "Nevertheless, these British writers have not worked consciously in the Austrian tradition, and in some respects they have gone further than the Austrians in emphasizing the unpredictability of economic events and the limited role of general equilibrium".
} 
1972) $)^{3}$. In the Austrian scheme of things, we look to economic theory

"..to help us understand how the decisions of individual participants in the market interact to generate the market forces which compel changes in prices, in outputs, and in the methods of production, and the allocation of resources" (Kirzner 1973: 6).

Presumably, post-Marshallians would agree with this causal-genetic approach to economic explanation. For example, George Richardson (1960: 107) argued that

"...a proper understanding and evaluation of the competitive economy [is] to be obtained by studying the actual process of adaptation and not by taking the illusory short cut...of equilibrium".

Where post-Marshallians and Austrians may differ, however, is rather in the attention paid to some of the constituent mechanisms of the market process, particularly firm behavior. Furthermore, rather than tending to see the market process as predominantly a matter of successful entrepreneurial discovery (as in Kirzner 1973), post-Marshallians tend to invest their view of the process with more distinctly evolutionary elements, explicitly emphasizing processes of differential firm growth ${ }^{4}$. This evolutionary, disequilibrium view arguably dates back to Marshall (Loasby 1990). So Marshall is where we should start in order to understand the post-Marshallians.

\section{Marshall and the New Theory of Value}

One sometimes becomes tempted to say that the important thing about Marshall is that he did not invent "intermediate microeconomics"; that particular type of "Marshallian" doctrine was developed by primarily Pigou, Viner and Robinson. Instead, Marshall - at least in his later years - saw the development of the mechanical theory of equilibrium as merely a stepping stone to the development of a more comprehensive and satisfactory theory of

\footnotetext{
${ }^{3}$ It should be noted that the post-Marshallian-Austrian economics connection strongly depends on which kind of Austrian economics one focuses on. I here primarily associate Austrian economics with Hayek (1937, 1945, 1946, 1973), Lachmann (1956, 1971, 1986), Kirzner (1973, 1986), and O'Driscoll \& Rizzo (1985)), rather than with the more Misesian branches of Austrian economics. Also pertinent is the interpretation of Marshall's work that is adopted. My understanding follows Loasby (1990) and O'Brien (1990) (rather than Shove, Frisch or Levine).

${ }^{4}$ Thus, Downie (1958) talked about the "transfer mechanism", and Richardson about (1960: 119) about "Efficient Selection". In contrast, Austrian interest in variety-retention-selection processes mostly relates to institutional evolution (see Hayek 1973), that is to say, to changes in the rules within which market processes take place.
} 
economic change, inspired by the work of Charles Darwin and particularly Herbert Spencer. That story is fairly well-known, as is the fact that the biologically inspired theory largely remained ill-developed (Thomas 1991).

From the beginning of the nineteen-twenties, Marshall's program seemed to be progressively accumulating empirical and theoretical anomalies. The Pigou-Clapham "boxes"-debate was the first serious manifestation of this. Crucially, in 1926 Piero Sraffa changed the terms of the "boxes"-debate from being a debate about the empirical significance of Marshallian categories to be a debate about the theoretical consistency of the Marshallian edifice. The focus changed from empirical to theoretical anomalies. Sraffa's message was that theorists either had to adopt monopoly-theory as the standard market theory or had to work with general equilibrium analysis. Sraffa himself clearly preferred the first option, and Joan Robinson followed him in this. As we know well today, however, in a somewhat longer perspective, the profession turned towards the second option.

The new value theory represented a true break with Marshall's theoretical edifice - rather than a continuation, refinement and elaboration of it. It is noteworthy that the new theoretical style that became dominant during the 1930s also had the effect of squeezing out the Mengerian tradition ${ }^{5}$. On the whole, the new value theory implied a successful suppression of processual approaches to economics. From a subjectivist or process perspective, this implied a substantial Kuhnian "loss of content" (O'Brien 1984): on an overall level, all of that in Marshall's, and also - more indirectly - Menger's, work which can be said to have had an "evolutionary", developmental, institutional or historical character was effectively eliminated by the new value theory.

That a clean break was involved is perhaps clearest with regard to the theory of the firm. Here, Marshall's analysis of organization, his "trees in the forest" metaphor, etc., all of which was designed to emphasize the essential heterogeneity of firms, were discarded in favor of the uniform equilibrium firm, which logically made evolutionary reasoning impossible and suppressed any coordination problems between firms.

\section{The Post-Marshallian and Austrian Rear-Guard Actions}

\footnotetext{
${ }^{5}$ For example, one of the most decisive events behind the elimination of the Austrian School was the debate with market socialists who had thoroughly adopted the new style. Arguably, it was a result of this debate that the Austrians began to understand their distinctiveness (Lavoie 1985; Foss 1994a; Vaughn 1994).
} 
Not everybody accepted the changes brought about by the new value theory. In hindsight, the two groups who delivered the most sophisticated and sustained critique of the new microeconomics were the post-Marshallians, primarily Philip Andrews, Jack Downie, Edith Penrose, and George Richardson, and the Austrians, particularly Hayek, Lachmann, and, somewhat later, Kirzner. Where Hayek's strictures (Hayek 1948) broadly centered on the suppression in the new value theory of the dispersal of knowledge and the unfortunate consequences of this for understanding the competitive process in its entirety, the postMarshallians had a somewhat more narrow orientation, and chose the firm in its market setting as their prime object of analysis.

Assuredly, both groups strongly criticized the conceptualization of competition in the new value theory, and promoted a process approach in its stead. It is telling in this respect to compare, for example, Hayek's "The Meaning of Competition" (1946) with Andrews' (1964) or Richardson's (1960) reflections on the same subject. Like the Austrians, the post-Marshallians all rejected the perfect competition framework for practically all analytical purposes. This was a matter of its flagrant descriptive unrealism (Andrews), its suppression of any scope for evolutionary (Downie) or developmental (Penrose) reasoning, and its logical inconsistencies and suppression of any coordination problems (Richardson).

Hand in hand with the rejection of the perfect competition framework went also a rejection of the "marginalist" theory of the firm (Andrews 1949, 1964; Downie 1958: chapter 2; Penrose 1959; Lee \& Earl 1993); in fact, one sometimes gets the impression particularly from Andrews' work - that perfect competition is rejected because it implies a distorted view of the firm. On the positive side, the post-Marshallians reacted by turning their attention to either detailing the behavior of oligopolistic firms (Penrose, Andrews), or to elaborating the evolutionary intentions in Marshall's work (Downie). The one attempt to keep an eye at both the firm and the industry level is represented by Richardson's overall work. Here we find both an emphasis on the skill and capability endowments of individual firms (Richardson 1972), and an emphasis on industry-level selection forces (1960: chapter $7)^{6}$.

\section{Subjectivism and Economic Change}

Apart from their shared interest in the firm, the post-Marshallians were also united in an

\footnotetext{
${ }^{6}$ This is despite a quite strong critique of Alchian (1950), which closely parallels Penrose's (1952) in criticizing Alchian's playing down the role of intention and rationality. However, evolutionary arguments are, however, not inconsistent with some measure of intention and rationality. It adds to the irony when it is recognized that Alchian explicitly saw his analysis as a continuation of Marshall's evolutionary thought (Alchian 1950: 19n).
} 
overall subjectivist perspective: Like the Austrians, they, most obviously Penrose (1959: 41) and Richardson, are subjectivists in the sense that they see subjectively held, dispersed and changing knowledge, as well as the expectations produced on the basis of this knowledge, as absolutely crucial for understanding economic events. As Penrose was at pains to emphasize (1959: chapter 2), interpretative frameworks differ over firms, and it is to a large extent such differences that are determinative of market dynamics. For example, the experience of the management team determines its interpretative framework and therefore the "productive opportunity set" it can conceive of (Penrose). It is the market that sorts among such interpretive frameworks; indeed, according to Downie (1958: 13) who did most out of this, the market acts as a Hayekian discovery procedure (Hayek 1978).

In other words, both traditions conceptualize the economic problem as one "...not only of allocative logic but of search and discovery" (Richardson 1971: 244; compare Hayek 1946, 1968), so that "...concentrating on growth and change rather than equilibrium" (Downie 1958: 7) is warranted. This change-oriented perspective is in both traditions accompanied by a perspective on institutions and organizations as devices for adapting to change. Such a perspective was clearly championed by Marshall when he argued that "organization" was intimately related to "...forecasting the future...and [the] willingness to make provisions for it" (1925: 139). It was later echoed in Hayek's claim that "...economic problems arise always and only in consequence of change" (1945: 82), and that this warranted attention to organizations and (primarily) institutions.

\section{Theory and Empirical Reality}

Where the post-Marshallians may perhaps diverge from the Austrians has to do with their strong empirical orientation. This led them to emphasize that conceptualizations of reality should be allowed to significantly influence theorizing, rather than the perception of economic reality being wholly determined by the theoretical armory at hand (as argued most directly by Lucas 1980). Therefore, case-studies were seen as an important way of furthering research (Penrose 1960; Lee \& Earl 1993).

This strongly empirical orientation, as well as the accompanying methodological perspective on the interaction between theory and empirical reality, may seem to clash headon with the apriorist tendency that has traditionally characterized (plagued?) Austrian economics. But need it be so? No other than von Mises (1949: 59-64) emphasized that the categories of pure economics could only be fully utilized in applied research when combined with insight in the meaning structures through which real-world actors orient themselves. This is the more interpretivistic - dating back to the Austrians' debt to the German 
hermeneutics of the nineteenth century - side of Austrian economics, perhaps best represented by the work of Ludwig Lachmann (1986). And this type of Austrian economics may not at all be in conflict with the "anthropological" (O'Brien 1985: 38) research strategy favored by some of the post-Marshallians (notably Andrews). In fact, a modern Austrian, Don Lavoie (1990), has even been close to endorsing Lester's attack on marginalism as against Machlup's defence, and has advocated precisely a more anthropological/interpretive approach to the study of firms.

\section{Summing up}

The similarities between Austrians and post-Marshallians are many respects more numerous than their similarities to formalist mainstream economics. They share the fundamental emphasis on subjectivism, dispersed knowledge, disequilibrium, and on the need for causalgenetic explanation; they emphasize the need to adapt to (unforeseen) economic change and view institutions and organizations in this light. Both are "economics of time and ignorance" (O'Driscoll \& Rizzo 1985), and their relative lack of awareness to each other arguably cannot be explained by inconsistent Weltanschauungen. Where they differ lies primarily in their focusing the basic disequilibrium, subjectivist stance in different ways.

Notably, the post-Marshallians and the Austrians differ in terms of attention paid to the firm. Whereas firm behavior and organization is probably the single most important problem area of post-Marshallian economics, it is almost entirely neglected in Austrian economics. Before I discuss this problem, I further examine the relation between postMarshallian and Austrian economics, focusing on Richardson's work. His work is for several reasons particularly interesting in the present context. For example, he stands out among the post-Marshallians as being explicitly influenced by Austrian economics. Possibly for this reason, the frequency of shared themes is remarkably high. As a result, Richardson's work is particularly likely to serve a bridging role between the two traditions.

\section{George Richardson:}




\section{Marshall and Hayek}

For more than twenty years, from the early nineteen-fifties well into the nineteen-seventies, George Richardson produced a string of extremely original contributions to the postMarshallian tradition, many of which were strongly mixed with Austrian spices. Thus, he is the first economist to forge explicit links between the two traditions. Although Marshall is arguably the major influence, Hayek's influence on Richardson almost rivals Marshall's. In particular, Hayek's famous 1936-essay, "Economics and Knowledge" left a strong imprint on Richardson's thinking (Richardson 1953: 136n, 1960: 6, 1993a,b) ${ }^{7}$. However, it is notable that those aspects of Marshall's work that seems to have inspired Richardson the most, are also those that are most broadly compatible with Austrian thinking. For example, the Marshallian influence is clearly present in Richardson's methodological discussions, such as in his scepticism towards analogies from physics (1953: 153, 1960: 41n), a view that any Austrian would clearly endorse (e.g., Hayek 1943).

Equally Marshallian is the warning against excessive reification of economic concepts, something which may "...distort our vision of the plain facts of economic life" (1971: 244). As Richardson further explains, the history of economics demonstrates how awareness of "...of important aspects of reality may be inhibited...by the particular conceptual framework we employ" (1960: 138). Austrians would be likely to agree with this. It has been a constant theme in Austrian economics that, most notably, the perfect competition framework is likely to seriously distort our comprehension of economic reality (for example, Hayek 1946). In this connection, Austrians would wish to point to the socalled "socialist calculation debate" as a particularly illuminating example: the fact that the market-socialists of the nineteen-thirties based their theorizing on the perfect competition model and was thought to have won the debate meant that attention to may relevant issues (identified by the Austrians) became suppressed for decades (Lavoie 1985; Foss 1994a: chapter 4). Although incentives and dispersed knowledged were formally treated in mechanism design models, the roles of tacit knowledge, process and discovery were neglected. From a subjectivist perspective, these models therefore cannot satisfactorily confront the real alternatives: the tacit and process aspects of the real world economic problem are suppressed.

\footnotetext{
${ }^{7}$ Though not Hayek's other writings. When "Information and Investment" was published, Richardson sent a copy to Hayek, expressing appreciation of his article, but got no reply. Political aspects may have played a role, since Richardson's somewhat more activistic emphasis on the need for government action in a market economy may not have been wholly congenial to Hayek's more radical outlook (Richardson 1993a). It should also be noted that there are no references in Richardson's work to other Austrians than Hayek, except for a brief and approving reference to Menger's liquidity theory of money (Menger 1871: chapter 8), which is correctly seen as anticipating Keynes' monetary theory (1960: 157n).
} 
Richardson's perspective on economic organization is quite similar to this: he rejects ascribing exorbitant amounts of knowledge to agents ${ }^{8}$, and emphasises that the problem of economic organization must begin from the Marshallian premise that in the real world "Organization aids knowledge" (Marshall 1925: 138). But before we can understand why organization aids knowledge, we must understand why (dispersed) knowledge raises a problem at all. In clarifying this, Richardson seems to have been strongly influenced by Hayek's (1937) carefully elaborated distinction between the pure logic of choice, which we utilize for understanding individual decisions, and the societal problem of coordination, which is a matter of making all the different pieces of knowledge mesh (for example, Richardson 1959: 224-225). According to Hayek (1937), economic theory had not successfully established a correspondence between these two different allocation problems, basically because of its suppression of the issue of how economic agents get access to knowledge that will allow them to implement equilibrium plan.

This is indeed a - perhaps, the - crucial theme in Richardson's writings, too. In fact, at least one of his articles (Richardson 1959) is essentially a restatement of the problems Hayek had identified in more Marshallian terms, and therefore explicitly formulated in the context of a production economy. However, Richardson basically supplies Marshallian answers to the Austrian problem of coordination; in a way, he suggests Marshallian "...statements about how knowledge is acquired and communicated" (Hayek 1937: 33). Let us take a brief look at how Richardson conceives of the problem and the answers he provides.

\section{Information and Investment}

Consistent with the research strategy he had been taught by his one-time thesis advisor, John Hicks, namely to go back to the older influential writers rather than to modern writers, Richardson opens "Information and Investment" with a critique of Walras. It is appropriate that Richardson's main work should begin with such a critique, for as he later recalled: "It was indeed while reading Walras that I came to realise the confusion at the core of the General Equilibrium Theory" (Richardson 1993a). Predictably, Walras is criticized for his

\footnotetext{
${ }^{8}$ Richardson's first published article (Richardson 1953) is a very Hayekian piece on welfare economics, written in the days where enthusiasm about social welfare-functions was strongest. Almost paraphrasing Hayek's famous 1945-article on "The Use of Knowledge in Society", Richardson argues that the economic problem of society in "...our theoretical system would most closely represent...that facing a single mind to which all the relevant knowledge regarding means and ends were known with certainty and as a whole; that which confronts us is entirely different...[T] he actual economic problem...is...to ensure that the fullest use will be made of the..knowledge which is dispersed among many minds" (p.136).
} 
specific way of suppressing with the coordination problem with the fictitious auctionarius. This leads into a more general critique of how economists have traditionally described "The Tendency to Equilibrium" (as the first chapter is called). Today such a discussion would probably have taken place under the title, "the stability problem" (Fisher 1983), that is to say, the problem of how economic agents can hope to implement consistent plans when they are initially ignorant about with whom, at what terms, when, where, etc. they can trade.

It is important to emphasize this informational interpretation of the stability problem, since it in its older (and non-informational) version implies an analogy to mechanics that was and remains wholly alien to Richardson's outlook (Richardson 1993b). The reason that the problem has to be cast in informational terms is essentially that

"..no direct connection can exist between objective conditions and purposive activity; the immediate relationship is between beliefs about relevant conditions and planned activities which it may or may not prove possible to implement" (1959: 224).

This subjectivist statement clearly echoes to Hayek's (1937: 44) earlier insight that "The equilibrium relationships cannot be deduced merely from the objective facts, since the analysis of what people will do can start only from what is known to them".

Although he is not without predecessors (e.g., Morgenstern 1935; Hayek 1937), Richardson present what is probably the most acute critique of economists' excessive preoccupation with equilibrium positions to the neglect of how these positions are actually attained, before Frank Hahn, Franklin Fisher and others voiced some the same concerns ten years later ${ }^{9}$. According to Richardson, the problems with the usual adjustment stories are that they are unrealistic, mechanical, ad hoc, and violate the principle of methodological individualism (1960: 24). All this implies that, in a methodological sense no satisfactory explanation of equilibrium has been provided; only a description of the explanandum, with a fundamentally ad hoc explanans tagged on.

However, it is more serious than that; for Richardson is strongly questioning the very possibility of demonstrating any tendency towards equilibrium within the Walrasian model. One can, for the sake of hypothesis, assume that somehow - for example, by pure luck - agents were somehow able to home in on an coordinated state. If in this situation a disequilibrium should develop, it will not be possible to return to the equilibrium. More generally, "...the familiar "general equilibrium of production and exchange" cannot properly be regarded as a configuration towards which a hypothetical perfectly competitive economy

\footnotetext{
${ }^{9}$ Strictly speaking, Arrow (1959) had voiced some - but by no means all - of the same concerns before. Of course, it was Arrow's contribution that became widely quoted, and not Richardson's much richer discussion.
} 
would gravitate" (1959: 19) ${ }^{10}$. So, as Joan Robinson is reported to have said, "In order to get into equilibrium, one has to be in equilibrium". Let us see why.

Suppose that producers are hit by some increase in demand that affects them all and is expected to persist. What will be their responses, how much plant should they order? The problem is that the information on other firms' investment decisions that would be necessary for calculating optimal investments is not available to anyone, given the assumptions of the model. It is not incorporated in any given Debreu type states of nature. Firms may guess, of course, but those guesses must involve the guesses of other firms, which would seem to lead into an infinite regress. The endogenous uncertainty created implies that there is no equilibrium in the sequence of guesses, which implies that there is no single exit solution for any agent in the system. This is how we end up with the proposition that

"A general profit opportunity, which is both known to everyone, and equally capable of being exploited by everyone, is, in an important sense, a profit opportunity for no one in particular" (1960: 57).

This counter-finality indicates the existence of an internal theoretical anomaly in the form of an internal contradiction deep at the heart of neoclassical economics, or at least general equilibrium economics. It is not merely that neoclassical economics does not contain any causal mechanisms that help us understand how order comes about, as Hayek (1937) argued; the problem is that the whole operation is condemned from the beginning: an institutionless Walrasian production economy simply cannot function ${ }^{11}$.

\section{Rationality and Ad Hockery}

In his critique of the Walrasian model, Richardson has two distinguished Austrian precursors: Like Hayek (1937), Richardson is criticizing the assumption that there is a direct connection between the allocation problem of the perfectly rational representative agent and market level allocation; in the absence of specification of the institutions under which agents interact, and therefore the information they may gain access to, there is no such connection.

\footnotetext{
${ }^{10}$ However, Richardson's version of perfect competition may differ somewhat from modern conceptions: his is a non-perfectly contestable (since investments are partially irreversible (1960: 50)), non-rational expectations set-up. Furthermore, absence of forward markets are implicitly assumed, so that expectations based on local knowledge must substitute. Well, as Richardson shows, such expectations in fact cannot substitute for forwardmarkets under atomism.

${ }^{11}$ Clearly, simple exchange economies would not experience the sort of coordination failures that Richardson describes.
} 
And like Morgenstern (1935), Richardson points out the problems of endogenous uncertainty that perfect rationality may imply. Mainstream economists are not quite ignorant about problems of endogenous uncertainty per se, although to the extent that they are discussed, it is mostly in the context of certain oligopolistic market structures. As Richardson demonstrated, however, the problem applies to all market structures. In terms of its overall scope, Richardson's critique of received theory has a superficial similarity with Sraffa's three decades older one in identifying an internal theoretical anomaly in price theory and in its concentration on the supply curve. However, his is by far the more fundamental.

Richardson is not only questioning the use of equilibrium theory in the absence of a sound stability theoretic foundation (1960: chapter 1), he is also pointing out that neoclassical economics has its amount of ad hoc theorizing. Fundamentally, this has to do with the kind of indeterminacy that Richardson highlighted in the Walrasian model, an indeterminacy that is most obvious in the case of dynamic adjustment processes and which is eliminated by routinely adding various ad hoc-devices to the formal theory. A catalogue of these devices would begin, of course, with Walras' auctioneer, continue with Milton Friedman's (1953) appeal to strong selection forces on the supply side of the market in order to justify maximization and equilibrium, and proceed to the ad hoc auctions that are routinely postulated in some of the modern neoclassical literature on innovation (see Reinganum 1989) and on capacity expansion problems in oligopolies when entry is allowed (Ghemawat 1987).

These devices allow the analyst to side-step precisely the adjustment problems that Richardson highlighted. However, they are essentially theoretically unrelated to the formal theory. For example, the evolutionary market-processes that Friedman (1953) appeals to do not incorporate maximization and equilibrium. But these processes are the basis on which the validity of these two concepts are really argued. Thus, a quite natural question to ask is, Why not take them seriously, that is, theoretically approach them (cf. Nelson \& Winter 1982)? By the same token, if our faith in the relative efficiency of the market system not only lies in ascribing rationality to agents, but also in the institutions and constraints the system incorporates, why not theoretically approach them, too? This would seem necessary, particularly when we consider the Richardsonian recognition that there cannot be exchange in isolation from market institutions.

\section{Institutions}

Much of modern economics has recently taken the "institutional turn", as witnessed by work on, for example, transaction cost economics, property rights theory, agency theory, etc. However, also economists who are not directly affiliated with the neo-institutionalist 
movement have argued for more attention being paid to the institutional dimension - and often for reasons that are closely akin to the problems that Richardson was taken up with. For example, in context of an examination of convergence to rational expectations equilibrium, Roman Frydman (1982) concluded that the possibility of demonstrating such convergence under decentralization are remote, very much in the same spirit that Richardson concluded that perfect competition could not be regarded as a configuration that a competitive system would approach. Furthermore, Frydman suggested that

"..in addition to information contained in market prices, social norms (in particular business practice) imposing some restrictions and coherence on the individual decisions and information generated by institutions external to the market may play important roles in understanding decentralized market processes" (p.664).

It is very much from a similar perspective that Richardson approaches "imperfections" and "business practices". For example, capital market imperfections limit the access to investment funds and thereby keep in check expansion plans, and price agreements, cartel arrangement, etc. play similar roles. They exist because they allow complementary investments to be coordinated and hinder excessive competitive investment in the face of, for example, unforeseen changes in demand. Thus, institutions are approached in terms of their ability to accomodate economic change, much like the way in which Mises (1936) and Hayek (1945) approached the market system.

As early as 1937, Hayek also noticed that the perfectly competitive ideal made it impossible to address the existence of a number of institutions. Focusing on the dissemination of knowledge, he noted that the dominance of the perfect competition model would "..go far to account for the fact that pure analysis seems to have so extraordinarily little to say about institutions, such as the press, the purpose of which is to communicate knowledge" (Hayek 1937: 55). Hayek found economic theory unable to come forward with a convincing answer to how plan-coordination came about in a decentralized economy, and it can be argued that it was basically this circumstance that led Hayek to leave economics and seek a solution to the coordination problem in the traditional classical-liberal emphasis on evolved institutions.

Thus, both Hayek and Richardson concentrate on "institutions" in a broad sense as the phenomena that dampen the coordination problem and eases adaptation to changed and perhaps unforeseen circumstances. However, Richardson seeks a solution that is internal to economic theory, while Hayek does not. Where Hayek (1973) focuses on society-wide and mostly tacit rules of behavior, Richardson focuses solely on industry-specific "imperfections", some of which are quite explicit (such as collusion). Therefore, Richardson 
may be seen as supplying Austrian economics with a much needed analysis of specific market institutions, since he addresses these institutions as solutions to essentially Austriantype coordination problems. Among the Austrians, such institutions only captured the interest of Lachmann (1956, 1986).

The importance of "imperfection" for the effective working of industry is perhaps most obvious in the case of the coordination of investment projects that are complementary to each other. Here Richardson is again linking up with an Austrian favorite theme, namely the intertemporal complementarity of capital goods (Hayek 1941; Lachmann 1956). The basic theme of Austrian capital theory - that production is staged and that capital goods stand in a relation of intertemporal complementarity to each other - was attacked by Frank Knight in the nineteen-thirties as a non-issue, and survived only in development economics and in a distorted form in input-output analysis. Coordination problems in the intertemporal chain of production was of course the main concern of the Austrian business cycle theory of the nineteen-thirties (Hayek 1931); coordination problems that could be avoided through appropriately chosen monetary policies.

In a sense, the efficient coordination of complementary investments is also a main message and a policy concern in Richardson's analysis; thus, here too he is reviving and elaborating an older Austrian theme. Where Richardson differs from the early Hayek is of course in denying that the price-mechanism generally will do the job of coordinating complementary investments unassisted. This is argued in much the same way as it is argued that the pure price-mechanism cannot yield an optimal amount of competitive investment (1960: 76-77). Again, "imperfections" such as reputation, trust, and contractual agreements perform the tasks of easing knowledge flows over stages of production and contributing commitments.

\section{Planning and Investments}

There is a direct, though neglected, link from Richardson's early work (1953, 1956, 1959, 1960) on coordination problems to his acclaimed work on inter-firm relations (1972). The link is provided by Richardson's 1969 consultancy report for the British Electrical and Allied Manufacturers' Association (BEAMA), "The Future of the Heavy Electrical Plant Industry", and his 1971 article on "Planning versus Competititon".

The report was written in the context of the aftermath of a coordination failure for complementary investments associated with projections of economic growth in the Labour Government's 1965 National Plan (Richardson 1969: 8); a coordination failure that Austrians may invoke in support of their views on public intervention. Specifically, there had 
been wide and unpredictable fluctuations taking place in the electricity authorities' demand for heavy plant; in fact, a massive overordering of generating equipment, which was the price of consistency with the Plan. This discoordination of complementary investments was only part of the problem; for there was also a problem of coordination of competitive investments that arose because of the particular organisation of the power station equipment industry. The industry in fact confronted the destructive situation that relates to the coordination of competitive investments under competititon so dramatically portrayed by Richardson in "Information and Investment". As a result, it was virtually impossible for firms in the industry to operate on a profitable basis under competitive tendering.

Given that Richardson's 1969 report was very much written in the context of indicative planning gone wrong, it is perhaps not surprising that he should turn his attention towards comparative systems issues. In addition to putting forward a number of fresh arguments on the particular issue under consideration, "Planning versus Competition" (1971) is also noteworthy for its anticipation of some of the central points in the much better known 1972 article on "The Organisation of Industry". It is here that Richardson for the first time systematically inquires into alternative forms of economic organization - markets, interfirm arrangements, firms - in a private property market economy.

\section{The Organisation of Industry}

Thus, we finally emerge at Richardson's 1972 masterpiece. Industry, says Richardson, may be thought of as composed of numerous "activities" (R\&D, manufacturing, sales and service etc.), which have to be carried out by firms with the requisite "capabilities". Activities which require the same or closely related capabilities are "similar". Similar activities are seldom complementary, since complementary activities typically occupy different stages of production. Firms find it expedient to concentrate on similar activities, since incorporating "dissimilar" activities bring diseconomies of scope and/or increased information costs. This forms a basis for a theory of "co-operation", that is of interfirm relations, such as long-term contracts, joint-ventures, licensing agreements etc.: firms enter into cooperative relations when they need access to upstream or downstream complementary but dissimilar activities. Activities that are "closely complementary" will typically be under common ownership.

In this view of industry, the existence of numerous bonds, ties, commitments etc. between firms, developed because activities may be dissimilar but complementary, stabilizes the system and secures its effective working. Richardsons work during the nineteen-sixties primarily focused on horizontal interfirm relations and agreements (Richardson, 1965a\&b, 1967), such as price notification schemes, and therefore primarily addressed the issue of the 
coordination of competitive investments. His 1972 article, partially preceded by the 1969 BEAMA consultancy report and the 1971 article, extended the focus to vertical arrangements, addressing complementary investments.

Clearly, the argument to a large extent turns on the tacit knowledge underlying capabilities; it is because this knowledge can only be transferred and acquired at large costs that firms avoid integrating dissimilar activities (cf. Demsetz 1988). And partly because of such tacitness, the individual firm will not normally have superior or even precise knowledge about the whole of the production process into which its products enter. It is likely that nobody will in fact possess all of this knowledge. However, to paraphrase Hayek (1945) with a bow to Richardson, "the marvel" is precisely that competition and cooperation ensure that effective use is made of capabilities that are not possessed by any single firm. Firms are not completely self-contained; as Richardson (1972: 885) points out, effective cooperation will normally require some knowledge of "neighbouring" capabilities (those possesed by other firms), so that "..their limited individual fields of vision sufficiently overlap so that..the relevant information is communicated" (Hayek 1945: 86).

Richardson also links up with the Austrian understanding of the market in a somewhat different way. In Richardson's perspective, much of "the organisation of industry" is a matter of discovering which capabilities are best for you (as a producer), where and when. Now, Hayek saw "The function of competition" as primarily a matter of teaching us "...who will serve us well; which grocer or travel agency, which department store or hotel, which doctor or solicitor, we can expect to provide the most satisfactory solution for whatever particular personal problem we may have to face" (1946: 97). Thus, one of the benefits of the market system, including its modes of competition and cooperation, is that it makes capabilities visible to the participants.

\section{Summing Up}

While Richardson focuses his basic insights in economic organization in ways that are often (due to the Marshallian heritage) different from Austrian economics, the fact that these insights are in themselves quite close to basic Austrian themes remains. For example, like Marshall (Loasby 1990), Richardson is concerned with the organization and growth of knowledge. But so is Hayek; indeed, his perhaps primary argument for market organization is precisely that it is (compared to central planning) a superior means of discovering and testing new knowledge, and he quite explicitly draws on the growth of knowledge literature in developing this argument (Hayek 1968).

Moreover, much of Richardson's work may be seen as complementary to an 
Austrian process view of the market. In this perspective, he supplies that analysis of market institutions, which is so sorely missing in most Austrian accounts of the market process. In, for example, Israel Kirzner's account of the entrepreneurial market process (Kirzner 1973), the entrepreneur is portrayed as acting in an institutional vacuum; this is one reason why it is so hard to meaningfully evaluate Kirzner's claim that the market process is inherently equilibrating. Moreover, like other post-Marshallians but unlike the Austrians, Richardson theorizes the firm. In the following section, I further explore the complementarity between Richardson's capabilities view and Austrian economics, focusing on the firm. I offer this as an example of a common hunting ground for the Austrian and post-Marshallian traditions.

\section{Austrian and Post-Marshallian Economics: The Theory of the Firm}

\section{Austrian Economics and the Theory of the Firm}

It has often been observed that Austrian economics does not feature a theory of the firm (O'Driscoll \& Rizzo 1985; Loasby 1989, 1992; Langlois 1992b; Foss 1994b; Minkler 1993). This is a paradoxical feature, since what may arguably be "the most obvious deficiency in Austrian economics" (Loasby 1989: 166) lies in the market process itself. Austrians have next to nothing to say about pricing, buyer-seller relations, vertical integration and other aspects of economic organization; in other words, one of the most important constituent mechanisms of the market process, namely firm behavior, is simply not theorized in Austrian economics. In contrast, firm behavior has captured the lion's share of interest among postMarshallians. This is perhaps not surprising, given that Marshall was the first economist (at least among the neoclassicals) to give much attention to the firm.

Elsewhere I have observed that it is really something of a doctrinal puzzle that the Austrians never came forward with a theory of the firm (Foss 1994b). This is so because they had so many of the necessary elements of modern theories of the firm, such as a basic understanding of the principal-agent relation (Mises 1981), dispersed knowledge (Hayek 1945), "routines" (broadly conceived) (Hayek 1973), knowledge costs (Hayek 1937), asset specificity and complementarity (Hayek 1931), and an emphasis on unexpected change (Hayek 1945). The reason for this apparent lack may well be that the Austrians were busy defending themselves against the attacks of Keynes, Sraffa, Knight and the market socialists. Another, more trivial reason, may simply be that they, like most other contemporary 
economists, were not interested in the firm, and therefore never thought of approaching firms in terms of the above theoretical insights.

\section{Malmgren (1961): Richardsonian Arguments and the Firm}

Whatever that may be, it is still possible to distill Austrian insigths of relevance to the theory of the firm. For example, in a splendid essay, Richard Langlois (1992b) argues that the Austrian (Hayekian) understanding of social institutions as spontaneously emerged and generalized rules of behaviour may be able to further the capabilities view of the firm, associated with post-Marshallians such as Penrose and Richardson, and evolutionary economists Nelson and Winter (1982). However, Langlois is not the first to forge links between Austrian economics and the post-Marshallian understanding of the firm. In an article published long ago, Harold Malmgren (1961) not only significantly furthered the Coasian (1937) view of the firm, but also managed to integrate Coase's insights with postMarshallian and Austrian insights ${ }^{12}$.

According to Malmgren, firms are "put together" for a number of reasons that have little to do with the modern standard view of firm organization, that is, as efficient institutional responses to potential misalignment of incentives (Holmstrom \& Milgrom 1994). Rather than transforming non-cooperative behavior in potential prisoners dilemma games to cooperative behavior, the role of firms is to provide an institutional setting that solves coordination type games (cf. Foss 1993; Langlois \& Robertson 1993). Thus, the "precedents" and "customs" of firms provide coordinating Schelling points, help to stabilize the expectations of input-owners, and therefore reduce transaction costs. Moreover, firms harmonize expectations in situations in which "...output and profitability of various production units are closely interdependent"; under such circumstances, "...the firm is formed to undertake decisions concerning all or some of the production units simultaneously, so as to maximize the joint profit and total output" (Malmgren 1961: 412). Notice that all this is essentially an application of Richardson's (1960) industry specific reasoning to the level of the firm: the firm is seen as an instance of particularly tight coordination between closely complementary assets and investments.

Arguably, the Richardson-Malmgren coordination view of the firm and vertical integration is in some dimension closer to Coase's (1937) original story than modern purportedly Coasian theories (such as Williamson 1985; Holmstrom \& Milgrom 1994) are.

\footnotetext{
${ }^{12}$ Malmgren acknowledges the help of Andrews and refers to Penrose (1959), Richardson (1960), Hayek (1937) and Lachmann (1956).
} 
Coase (1937) says nothing about misaligned incentives and emphasizes the superior adaptability - the superior coordinating capabilities - of the firm for some (by him unspecified) activities. These activities may typically involve closely complementary activities, and particularly changes in closely complementary activities are needed. Here Richardson (1960: 83-84) points out that

"An entrepreneur may believe that only by gaining some degree of control over the firm responsible for some complementary investment will he be fully assured of it being undertaken; vertical integration may be carried out with this end in view".

As Morris Silver (1984) argued in a neglected contribution a decade ago, the economic reason why integration may be necessary under such circumstances is because of the presence of prohibitive communication costs; the relevant knowledge is wholly "impacted" in the entrepeneur's "vision" or in the capabilities of the firm ${ }^{13}$. As Malmgren put it, "...the firm predicts the costs of production of its commodities better than the market could" (1961: 405), and therefore may have difficulties entering into satisfactory market contracts with outside suppliers (see also Penrose 1959: 148). In other words, economic organization largely reflects the economics of conservation of expenditures on knowledge transmission (Demsetz 1988).

This view should appeal to Austrians and post-Marshallians alike; it should appeal to post-Marshallians because it is perfectly consistent with an overall capabilities view of the firm; it should appeal to Austrians because it takes seriously the subjectivist positions that "different men know different things" (Hayek), that "different men have different thoughts" (Lachmann), and that communicating knowledge and thoughts is not costless. It should appeal to both groups because it explicitly places economic organization in a dynamic context.

\section{Economic Organization and Flexibility}

The idea, promoted by Coase, Malmgren, and Richardson, that organizations and institutions may derive their efficiency rationales from their ability to react to economic change - that is, from "the need for adaptability" (Richardson 1960: chapter 8) - is one that should be sympathetic to Austrians. For example, Menger's (1871) liquidity theory of money entails a notion of money as a flexibility providing asset. And clearly Mises (1936) and

\footnotetext{
${ }^{13}$ See Langlois (1992a), Langlois \& Robertson (1993) and Foss (1993) for analyses in the spirit of Silver.
} 
Hayek (1945) saw the main virtue of the market as its superior ability to flexibly react to unexpected change (Foss 1994a). Ludwig Lachmann (1956: 131) extended the perspective to the entrepreneur:

"We are living in a world of unexpected change; hence, [asset] combinations...will ever be changing, will be dissolved and reformed. In this activity, we find the real function of the entrepreneur".

Although the Austrians never explicitly applied the idea of institutions as embodying responses to change to the firm, we may, however, tentatively extend their perspective by suggesting that "the real function of the firm" may lie in rapidly deploying assets in the way Lachmann saw the entrepreneurial role.

Starting a firm is one way of capturing rents on specific human capital; one that may be particularly attractive to people with entrepreneurial abilities, since it will for a variety of reasons be hard to trade entrepreneurial services in the market (information impactedness, moral hazard problems, etc.). Thus, in an Austrian perspective, firms may be seen as means to realize entrepreneurial visions that would not be realized in their absence. In his attempt to carry out his entrepreneurial plan, the entrepreneur will not bring all the capabilities that are complementary to his own entrepeneurial capabilities under his own direction; the services of capabilities that are not closely complementary can normally be acquired without problems in the market. But "in a world of unexpected change", there will sometimes arise a need for new asset combinations and new inputs. Unexpected change feed plan revisions; and such revisions may have implications for the boundaries of the firm. The reason? The change of the asset mix that is necessary for realizing the revised plan may require new inputs from new activities and capabilities, some of which may now be closely complementary to the firm/the entrepreneur. As Richardson (1972) tells us, closely complementary (similar) activities and their underlying capabilities should be governed inside the firm. Furthermore, as Coase (1937) and Malmgren (1961) suggest, firm organization may have cost advantages relative to the market in rapidly redeploying assets (of the sort described by Silver (1984), Langlois (1992), Langlois \& Robertson (1993), Foss (1993)).

Thus, if markets, in the Austrian tradition, may be seen to incorporate capabilities of flexible adaptation to unforeseen change (Mises 1936; Hayek 1945), firms may be seen in much the same light (Richardson 1960: chapter 8; Malmgren 1961) ${ }^{14}$. This perspective

\footnotetext{
${ }^{14}$ As Brian Loasby (1993a) argues, the market is an institutional structure that largely exists by virtue of its flexible ability to supply options for future contracts, whereas the firm is an institutional structure that exists because of its provision of contracts for future options. Thus, they are both devices for creating and preserving the possibilities of future trade when the future is uncertain to the extent that present commitments cannot be justified; they derive their value to economic agents from these characteristics.
} 
on both firms and markets as flexibility providing institutions is one that dispels simplistic ideas of the one as inherently superior to the other in terms of flexibility; an idea that has marred much of the debate on "Fordism vs Flexible Specialization". Clearly, firms may sometimes be more flexible than markets; Alfred Chandler's work in business history is testimony to that. On the other hand, decentralized networks of firms may be more flexible in terms of rapidly testing a number of, for example, technological designs; however, as William Lazonick (1991) argues there are several historical examples (particularly British examples) of decentralized networks of firms being unable to adopt new (systemic) innovations, thus being in some sense inflexible. In other words, what may count more than the kind of economic organization is the kind of capabilities that are involved.

\section{Conclusion}

I have argued that Austrians and post-Marshallians share some important characteristics that set them apart from the mainstream in modern economics. Considerations of space has only allowed me to scratch the surface; more specific similarities and dissimilarities have not been discussed, merely the important overall shared characteristics. These characteristics have to do with a subjectivist perspective on knowledge, an emphasis on disequilibrium, and a concern with institutional change. Another way to phrase the issue is that the Austrians and the post-Marshallians are united in a concern with those aspects of the classical (particularly Smithian) edifice that although they survived the marginalist revolution (primarily in Marshall and Menger's work), became suppressed with the advent of the formalist revolution in the nineteen-thirties: change, evolution, institutions, and a concern with the role of knowledge in economic life. The features are particularly visible in the work of George Richardson; as a result, his work is particularly likely to serve as a bridge between the two traditions.

In terms of today's economics, the natural allies of post-Marshallians and Austrians are neo-institutionalists and evolutionary economists. But they may also benefit from dialogue. That dialogue seems to be slowly beginning. For quite some years, Brian Loasby has done much to get it started (Loasby 1989, 1992, 1993a,b), and the recent work of Richard Langlois (1992a,b), Alanson P. Minkler (1993) and Roger Koppl (1993) may in many respects be seen as attempts to combine Austrian and post-Marshallian insights. As I have indicated, the liaison may begin with the theory of the firm, since modern work on the capabilities view of the firm already incorporates notions that are very close to both Austrian and post-Marshallian ideas. 


\section{References}

Andrews, P.W.S. (1949) : Manufacturing Business. London: MacMillan.

Andrews, P.W.S. (1964) : On Competition in Economic Theory. London: Macmillan.

Arrow, K.J. (1959) : Toward a Theory of Price Adjustment. In M. Abramovitz (ed.) (1959)

: The Allocation of Economic Resources: Essays in Honor of Bernard Francis Haley.

Stanford: Stanford University Press.

Caldwell, B. \& S. Böhm (eds.) (1992) : Austrian Economics: Tensions and New Directions. Boston: Kluwer.

Coase, R.H. (1937) : The Nature of the Firm. In Barney, J.B. and W.G. Ouchi (eds.) (1988)

: Organizational Economics. San Francisco: Jossey-Bass Publishers.

Demsetz, H. (1988) : The Theory of the Firm Revisited. Journal of Law, Economics, and Organization 4: 141-162.

Downie, J. (1958) : The Competitive Process. London: Duckworth.

Earl, P.E. (1983) : A Behavioral Theory of Economists' Behavior. In A.S. Eichner (ed.) (1983) : Why Economics is not Yet a Science. London: Macmillan.

Earl, P.E. (1993) : Whatever Happened to Andrews' Industrial Economics. In F.S. Lee \& P.E. Earl (1993).

Fisher, F.M. (1983) : Disequilibrium Foundations of Equilibrium Economics. Cambridge: Cambridge University Press.

Foss, N.J. (1993) : The Theory of the Firm: Contractual and Competence Perspectives. Journal of Evolutionary Economics 3: 127-144.

Foss, N.J. (1994a) : The Austrian School and Modern Economics: Essays in Reassessment. Copenhagen: Copenhagen Business School Press.

Foss, N.J. (1994b) : The Theory of the Firm: The Austrians as Precursors and Critics of Contemporary Theory. Review of Austrian Economics 7: 31-65.

Foss, N.J. (1994c) : Cooperation is Competition: George Richardson on Coordination and Interfirm Relations. British Review of Economic Issues 16: 25-49.

Foss, N.J. (1995) : The Economic Doctrines of an Austrian Marshallian: George Barclay Richardson. Journal of Economic Studies 22: 23-44.

Friedman, M. (1953) : The Methodology of Positive Economics. In idem. (1953) : Essays on Positive Economics. Chicago: University of Chicago Press. 
Frydman, R. (1982) : Towards an Understanding of Market Processes: Individual Expectations, Learning and Convergence to Rational Expectations Equilibrium. American Economic Review 72: 652-668.

Ghemawat, P. (1986) : Investment in Lumpy Capacity. Journal of Economic Behavior and Organization 8: 265-277.

Hayek, F.A.v. (1931) : Prices and Production. London: Routledge.

Hayek, F.A.v. (1937) : Economics and Knowledge. In idem. (1948).

Hayek, F.A.v. (1941) : The Pure Theory of Capital. Chicago: University of Chicago Press.

Hayek, F.A.v. (1943) : The Facts of the Social Sciences. In idem. (1948).

Hayek, F.A.v. (1945) : The Use of Knowledge in Society. In idem. (1948).

Hayek, F.A.v. (1946) : The Meaning of Competition. In idem. (1948).

Hayek, F.A.v. (1948) : Individualism and Economic Order. Chicago: University of Chicago Press.

Hayek, F.A.v. (1968) : Competition as a Discovery Procedure. In idem. (1978) : New Studies in Philosophy, Politics, Economics, and the History of Ideas. London: Routledge.

Hayek, F.A.v. (1973) : Law, Legislation, and Liberty, Vol.1: Rules and Order. Chicago: University of Chicago Press.

Holmstrom, B. \& P. Milgrom (1994) : The Firm as an Incentive System. American Economic Review 84: 972-991.

Kirzner, I.M. (1973) : Competition and Entrepreneurship. Chicago: University of Chicago Press.

Kirzner, I.M. (ed.) (1986) : Subjectivism, Intelligibility, and Economic Understanding: Essays in Honor of Ludwig M. Lachmann. London: Macmillan.

Koppl, R. (1992) : Invisible-Hand Explanations and Neoclassical Economics: Towards a Post-Marginalist Economics. Journal of Institutional and Theoretical Economics 148: 292313.

Lachmann, L.M. (1956) : Capital and Its Structure. 1978 ed. Kansas City: Sheed Andrews and McNeel.

Lachmann, L.M. (1986) : The Market as an Economic Process. Oxford: Basil Blackwell.

Langlois, R.N. (1992a) : Transaction Cost Economics in Real Time. Industrial and 
Corporate Change 1: 99-127.

Langlois, R.N. (1992b) : Orders and Organizations: Toward an Austrian Theory of Social Institutions. In B. Caldwell \& S. Böhm (1992).

Langlois, R.N. \& P. Robertson (1993) : Business Organization as a Coordination Problem: Towards a Dynamic Theory of the Boundaries of the Firm. Business and Economic History 22: $31-41$.

Lavoie, D. (1985) : Rivalry and Central Planning. Cambridge: Cambridge University Press.

Lavoie, D. (1990) : Hermeneutics, Subjectivity, and the Lester/Machlup Debate: Toward a More Anthropological Approach to Empirical Economics. In idem. (ed.) (1990) : Hermeneutics and Economics. Boston: Kluwer.

Lazonick, W. (1991) : Business Organization and the Myth of the Market Economy. Cambridge: Cambridge University Press.

Lee, F.S. \& P.E. Earl (1993) : The Economics of Competitive Enterprise: Selected Essays of P.W.S. Andrews. Aldershot: Edward Elgar.

Littlechild, S. (1977) : The Fallacy of the Mixed Economy. London: Institute of Economic Affairs.

Loasby, B.J. (1976) : Choice, Complexity, and Ignorance. Cambridge: Cambridge University Press.

Loasby, B.J. (1989) : The Minds and Methods of Economists. Cambridge: Cambridge University Press.

Loasby, B.J. (1990) : Firms, Markets, and the Principle of Continuity. In J.K. Whitaker (ed.) (1990) : Centenary Essays on Alfred Marshall. Cambridge: Cambridge University Press.

Loasby, B.J. (1992) : Market Co-ordination. In B.J. Caldwell \& S. Böhm (1992).

Loasby, B.J. (1993a) : Understanding Markets. Working Paper, University of Stirling.

Loasby, B.J. (1993b) : Change and Evolution: A Counterfactual History of Twentieth Century Economics. Papers on Economics and Evolution 9304, edited by the European Study Group for Evolutionary Economics.

Lucas, R.E. (1980) : Methods and Problems in Business Cycle Theory. In idem. (1981) : Studies in Business Cycle Theory. Cambridge: MIT Press.

Malmgren, H.B. (1961) : Information, Expectations and the Theory of the Firm. Quarterly Journal of Economics 75: 399-421. 
Marshall, A. (1925) : Principles of Economics. London: Macmillan.

Menger, C. (1871) : Principles of Economics. New York: New York University Press.

Minkler, A.P. (1993) : The Problem With Dispersed Knowledge: Firms in Theory and Practice. Kyklos 46: 569-587.

Mises, L.v. (1936) : Socialism. 1981 ed. Indianapolis: Liberty Press.

Morgenstern, O. (1935) : Perfect Foresight and Economic Equilibrium. In A. Schotter (ed.) (1976) : Selected Writings of Oskar Morgenstern. New York: New York University Press.

Nelson, R.R. \& S.G. Winter (1982) : An Evolutionary Theory of Economic Change. Harvard: Belknap Press.

O'Brien, D.P. (1984) : The Evolution of the Theory of the Firm. In F.H. Stephen (ed.) (1984) : Firms, Organization, and Labour. London: Macmillan.

O'Brien, D.P. (1985) : Research Programmes in Competitive Structure. Journal of Economic Studies 10: 29-51.

O'Brien, D.P. (1990) : Marshall's Industrial Analysis. Scottish Journal of Political Economy 37: 61-84.

O'Driscoll, G.P. \& M. Rizzo (1985) : The Economics of Time and Ignorance. Oxford: Basil Blackwell.

Penrose, E.T. (1952) : Biological Analogies in the Theory of the Firm. American Economic Review 42: 804-819.

Penrose, E.T. (1959) : The Theory of the Growth of the Firm. Oxford: Oxford University Press.

Penrose, E.T. (1960) : The Growth of the Firm - A Case Study: The Hercules Powder Company. Business History Review 34: 1-23.

Prahalad, C.K. \& G. Hamel (1990) : The Core Competence of the Corporation. Harvard Business Review 66: 79-91.

Reinganum, J.F. (1989) The Timing of Innovation: Research, Development, and Diffusion. In R. Schmalensee and R.D. Willig (eds.) (1989) : Handbook of Industrial Organization. Amsterdam: North-Holland.

Richardson, G.B. (1953) : Imperfect Knowledge and Economic Efficiency. Oxford Economic Papers 5: 136-156.

Richardson, G.B. (1956) : Demand and Supply Reconsidered. Oxford Economic Papers 8: 
113-126.

Richardson, G.B. (1959) : Equilibrium, Expectations and Information. The Economic Journal 69: 223-237.

Richardson, G.B. (1960/1990) : Information and Investment. Oxford: Oxford University Press.

Richardson, G.B. (1965) : The Theory of Restrictive Trade Practices. Oxford Economic Papers 17: 432-449.

Richardson, G.B. (1967) : Price Notification Schemes. Oxford Economic Papers 19: 359369.

Richardson, G.B. (1969) : The Future of the Heavy Electrical Plant Industry. London: British Electrical and Allied Manufacturers' Assocation Ltd.

Richardson, G.B. (1971) : Planning versus Competition. Annex to Richardson (1960/1990).

Richardson, G.B. (1972) : The Organisation of Industry. Economic Journal 82: 883-896.

Richardson, G.B. (1975) : Adam Smith on Competition and Increasing Returns. In Skinner, A.S. and T.Wilson (eds.) : Essays on Adam Smith. Oxford: Clarendon Press.

Richardson, G.B. (1993a) : Letter to Nicolai Foss, May 14.

Richardson, G.B. (1993b) : Letter to Nicolai Foss, October 19.

Silver, M. (1984) : Enterprise and the Scope of the Firm. Aldershot: Martin Robertson.

Sraffa, P. (1926) : The Laws of Return under Competitive Conditions. In Stigler, G.J. and K.E. Boulding (eds.) (1952) : Readings in Price Theory. Homewood: Irwin.

Streissler, E. (1972) : To What Extent was the Austrian School Marginalist? History of Political Economy 6: 426-441.

Thomas, B. (1991) : Alfred Marshall on Economic Biology. Review of Political Economy 3: 1-14.

Vaughn, K.I. (1994) : Austrian Economics in America: The Migration of a Tradition. Cambridge: Cambridge University Press.

Williamson, O.E. (1985) : The Economic Institutions of Capitalism. New York: Free Press. 


\section{$\mathbf{D}_{\text {anish }} \mathbf{R}_{\text {esearch }} \mathbf{U}_{\text {nit for }} \mathbf{I}_{\text {ndustrial }} \mathbf{D}_{\text {ynamics }}$}

The Research Programme

The DRUID-research programme is organised in 3 different research themes :

\section{- The firm as a learning organisation}

- Competence building and inter-firm dynamics

- The learning economy and the competitiveness of systems of innovation

In each of the three areas there is one strategic theoretical and one central empirical and policy oriented orientation.

\section{Theme A: The firm as a learning organisation}

The theoretical perspective confronts and combines the ressource-based view (Penrose, 1959) with recent approaches where the focus is on learning and the dynamic capabilities of the firm (Dosi, Teece and Winter, 1992). The aim of this theoretical work is to develop an analytical understanding of the firm as a learning organisation.

The empirical and policy issues relate to the nexus technology, productivity, organisational change and human ressources. More insight in the dynamic interplay between these factors at the level of the firm is crucial to understand international differences in performance at the macro level in terms of economic growth and employment.

\section{Theme B: Competence building and inter-firm dynamics}

The theoretical perspective relates to the dynamics of the inter-firm division of labour and the formation of network relationships between firms. An attempt will be made to develop evolutionary models with Schumpeterian innovations as the motor driving a Marshallian evolution of the division of labour.

The empirical and policy issues relate the formation of knowledge-intensive regional and sectoral networks of firms to competitiveness and structural change. Data on the structure of production will be combined with indicators of knowledge and learning. IOmatrixes which include flows of knowledge and new technologies will be developed and supplemented by data from case-studies and questionnaires. 


\section{Theme C: The learning economy and the competitiveness of systems of innovation.}

The third theme aims at a stronger conceptual and theoretical base for new concepts such as 'systems of innovation' and 'the learning economy' and to link these concepts to the ecological dimension. The focus is on the interaction between institutional and technical change in a specified geographical space. An attempt will be made to synthesise theories of economic development emphasising the role of science based-sectors with those emphasising learning-by-producing and the growing knowledge-intensity of all economic activities.

The main empirical and policy issues are related to changes in the local dimensions of innovation and learning. What remains of the relative autonomy of national systems of innovation? Is there a tendency towards convergence or divergence in the specialisation in trade, production, innovation and in the knowledge base itself when we compare regions and nations?

\section{The Ph.D.-programme}

There are at present more than $10 \mathrm{Ph}$.D.-students working in close connection to the DRUID research programme. DRUID organises regularly specific Ph.D-activities such as workshops, seminars and courses, often in a co-operation with other Danish or international institutes. Also important is the role of DRUID as an environment which stimulates the Ph.D.-students to become creative and effective. This involves several elements:

- access to the international network in the form of visiting fellows and visits at the sister institutions

- participation in research projects

- access to supervision of theses

- access to databases

Each year DRUID welcomes a limited number of foreign Ph.D.-students who wants to work on subjects and project close to the core of the DRUID-research programme.

\section{External projects}

DRUID-members are involved in projects with external support. One major project which covers several of the elements of the research programme is DISKO; a comparative analysis of the Danish Innovation System; and there are several projects involving international co-operation within EU's 4th Framework Programme. DRUID is open to host other projects as far as they fall within its research profile. Special attention is given to the communication of research results from such projects to a wide set of social actors and policy makers. 


\title{
DRUID Working Papers
}

96-1 Lundvall, Bengt-Åke: The Social Dimension of the Learning Economy. (ISBN 87-7873-000-7)

96-2 Foss, Nicolai J.: Firms, Incomplete Contracts and Organizational Learning.

(ISBN 87-7873-001-5)

96-3 Dalum, Bent and Villumsen, Gert:Are OECD Export Specialisation Patterns 'Sticky?' Relations to the Convergence-Divergence Debate. (ISBN 87-7873-002-3)

96-4 Foss, Nicolai J: Austrian and Post-Marshallian Economics: The Bridging Work of George Richardson. (ISBN 87-7873-003-1)

96-5

Andersen, Esben S., Jensen, Anne K., Madsen, Lars and Jørgensen, Martin: The Nelson and Winter Models Revisited: Prototypes for Computer-Based Reconstruction of Schumpeterian Competition. (ISBN 87-7873-005-8)

\section{Information for subscribers.}

Subscription price for 1996 is 600 DKR (about 20 papers). The rate for single issues is $40 \mathrm{DKR}$. It is possible to make a commitment to an exchange of papers from related departments or research teams. All correspondence concerning the DRUID Working Papers should be send to:

\author{
Mette Madsen \\ Fibigerstræde 4, \\ DK-9220 Aalborg OE \\ Tel. 45981542 11-2945 \\ Fax. 4598156013 \\ E-mail: mm@business.auc.dk
}

